\title{
A Study on the Evaluation of Port Competitiveness in Busan Port and Shanghai Port
}

\author{
A-Rom Kim, Jing Lu \\ Transportation Management Colleague, Dalian Maritime University, Dalian, China \\ Email: arkim@dlmu.edu.cn
}

Received 9 April 2016; accepted 23 April 2016; published 27 April 2016

Copyright (C) 2016 by authors and OALib.

This work is licensed under the Creative Commons Attribution International License (CC BY). http://creativecommons.org/licenses/by/4.0/

(c) (i) Open Access

\section{Abstract}

This study seeks the strategy alternatives for continuous port competitiveness of Busan port improvement in rapidly changing of environment in Northeast Asia shipping. This study aims: 1) to compare port competitiveness of Busan and Shanghai port using entropy weigh TOPSIS; 2) to seek ways to improve port competitiveness of Busan port. After searching the related criteria on port competitiveness factors for analysis, the main criteria are divided into two categories: port throughput (port throughput, throughput change rate, and transshipment cargo volume and transshipment cargo rate), port facilities (depth, the number of $\mathrm{C} / \mathrm{C}$, berth length, the number of berth, total area, storage area) criteria of Busan and Shanghai port. The empirical results indicate that Shanghai port is more competitive than Busan port in total competitiveness and port throughput criteria, and Busan port is more competitive than Shanghai port in port facilities criteria.

\section{Keywords}

Port Competitiveness, TOPSIS, Entropy, Port Throughput, Port Facility, Busan Port, Shanghai Port

Subject Areas: Economics, Operations Management, Strategic Management

\section{Introduction}

In the 21st century, the globalization is accelerating and cross-border economic war is going on. In this environment, the center of global economy is moving to East Asia around China. Around 50\% of the worldwide container throughput is moving through Asia, therefore competition for hub port among Asian ports is strong more and more. Especially, in order to attract the transshipment cargo, competition exists various ways: such as port services and aggressive marketing strategy and so on 
Busan port of Korea, Korean government and Busan port authority have implemented strategies around Busan port for the main hub port of North-East Asia, they opened the Busan new port and invested port facilities accordingly. However, these efforts of Korean government and Busan port authority are experiencing many difficulties due to the rapid growth of Chinese ports.

The enlargement of Chinese ports, because Korean ports have relatively degraded port competitiveness, it Decrease port throughput of Korean ports more decrease than Chinese ports. Focus on these decreasing of port throughput and changing the international environment, Korean government is building new ports in Busan and Inchon. Therefore, if we analyzed the determinants of port competitiveness, it can help to prevent the port throughput decreased. At the same time, and it also can help to augment their own port throughput and transshipment cargo volume.

In the keen competition among North-East Asia main ports, it needs to be more competitive through ensuring port competitiveness. In this context, this study seeks the alternatives in response to the rapidly growing Chinese ports and growing port competitiveness strategies continually through comparing the port competitiveness in Busan port of Korea and Shanghai port of China.

Therefore, in this study, we seek previous study about port competitiveness and the component for port competitiveness, and then we examine the definition of TOPSIS method and applications of TOPSIS method. We selected 2 large categories (total 10 variables) for analyzing container port competitiveness in Busan port and Shanghai port in this study through literature review. Finally, we analyze the port competitiveness of Busan port and Shanghai port by entropy weighted TOPSIS.

\section{Literature Review}

The port competitiveness is variously defined by each researcher in several ways. Port competitiveness has led to competition between ports and it has a competitive advantage. In other words, because it shows a criterion to ship owners and shippers for selecting port through various functions for competitive advantage. Therefore, it can be utilized as an indicator that prepares a countermeasure because it identifies the opportunities and threats of port.

Saeed [1] presented the results of an empirical study conducted by distributing questionnaires to shipping agents working for foreign principals in Karachi, Pakistan. In this study, a linear model is developed in which the dependent variable is total stay (in hours). The independent variables are vessel type, vessel size, total TEUs (twenty-foot equivalent units), vessel frequency and past visits of the shipping line. All the coefficients are significant.

Sayareh and Alizmini [2] using TOPSIS and AHP found that the working time, stevedoring rate, safety, port entrance, sufficient draft, capacity of port facilities, operating cost, number of berths, ship channelizing, and international policies are critical factors for selecting container seaport in the Persian Gulf.

Other studies attempting to identify and explain the various factors in shippers' port choice using various methodologies include Mangan et al. [3], Nir et al. [4], Tiwari et al. [5], Malchow and Kanafani [6] [7], Yeo et al. [8] [9], Tongzon [10]-[12] and Ugboma et al. [13].

Table 1 provides a literature reviews on port competitiveness.

According to literature review, we found that not only port competitiveness but also the components of port competitiveness were differently analyzed by researchers. Thus, we selected 2 large categories (total 10 variables) for analyzing container port competitiveness in Busan port and Shanghai port in this study through literature review.

\section{Theoretical Consideration}

\subsection{The Concept of TOPSIS}

The concept of TOPSIS (Technique for Order Preference by Similarities to Ideal Solution) is a technique for solving the Multiple Criteria Decision Making problems.

As a method of comprehensive evaluation of distance, the chosen alternative should have the shortest distance from the Positive Ideal Solution (PIS), and also have the farthest distance from the Negative Ideal Solution (NIS). 
Table 1. Literature review on port and port competitiveness.

\begin{tabular}{|c|c|c|}
\hline & Author (s) & Research Findings \\
\hline 1 & $\begin{array}{l}\text { Saeed et al. [1], Grosso and Monteiro [14], } \\
\text { Song and Yeo et al. [15], Lirn et al. [16], Cullinane et al. [17] }\end{array}$ & $\begin{array}{l}\text { Cargo handling facilities and ability } \\
\text { to handle large volume of cargo }\end{array}$ \\
\hline 2 & $\begin{array}{l}\text { Tongzon [12], Grosso and Monteiro [14], } \\
\text { Yeo et al. [9], Song and Yeo [15] }\end{array}$ & Seaport service level \\
\hline 3 & Saeed et al. [1], Song and Yeo [15], Tongzon [10] [12], & Cranes efficiency and number of them \\
\hline 4 & $\begin{array}{l}\text { Grosso and Monteiro [14], Yeo et al. [9], } \\
\text { Malchow [7], Song and Yeo [15] }\end{array}$ & $\begin{array}{l}\text { Operation cost (port and cargo/passenger dues, } \\
\text { berth charges, victualling, hire of handling equipment, } \\
\text { pilotage, towage and passenger and cargo handling costs) }\end{array}$ \\
\hline 5 & Tongzon [10] [12], Grosso and Monteiro [14] & Port productivity \\
\hline 6 & Tongzon [12], Tiwari et al. [5] & Number of routes offered at the port \\
\hline 7 & Tongzon [12], Saeed et al. [1], Grosso and Monteiro [14] & Availability and capacity of port facilities \\
\hline 8 & $\begin{array}{l}\text { Tongzon [12], Grosso and Monteiro [14], Yeo et al. [9], } \\
\text { Malchow and Kanafani [7], Tiwari et al. [5], Lirn et al. [16] }\end{array}$ & $\begin{array}{l}\text { Efficient intermodal links to the port } \\
\text { (road, rail, air, feeder etc.) }\end{array}$ \\
\hline 9 & Saeed et al. [1], Tongzon [12], Chang et al. [17] & Number of berths availability \\
\hline
\end{tabular}

\subsection{The Steps of TOPSIS}

- Step 1: Construct the initial matrix

In this step, it is listed in the attributes depending on the type of them by a matrix. Initial matrix $\left(x_{i j}\right)_{m \times n}$ is as follows:

$$
\left(x_{i j}\right)_{m \times n}=\left(\begin{array}{cccc}
x_{11} & x_{12} & \cdots & x_{1 n} \\
x_{21} & x_{22} & \cdots & x_{2 n} \\
\vdots & \vdots & & \vdots \\
x_{m 1} & x_{m 2} & \cdots & x_{m n}
\end{array}\right)
$$

Here, $i=1,2, \cdots, m, j=1,2, \cdots, n$

- Step 2: Construct the normalized matrix.

It transforms various dimensional attributes into non-dimensional attributes, which allows comparing among criteria in this step. Normalized matrix $\left(p_{i j}\right)_{m \times n}$ is as follows:

$$
P=\left(p_{i j}\right)_{m \times n}=\left(\begin{array}{cccc}
p_{11} & p_{12} & \cdots & p_{1 n} \\
p_{21} & p_{22} & \cdots & p_{2 n} \\
\vdots & \vdots & & \vdots \\
p_{m 1} & p_{m 2} & \cdots & p_{m n}
\end{array}\right)
$$

Here, $p_{i j}=x_{i j} / \sqrt{\sum_{i=1}^{m}\left(x_{i j}\right)^{2}}$

- Step 3: Calculate the entropy of each attribute j.

$$
e_{j}=-/ \sum_{i=1}^{m} p_{i j} \times \log \left(p_{i j}\right)
$$

- Step 4: Determine weight.

The normalized weighted coefficient $w_{j}$ is as follows:

$$
w_{j}=1 /\left(e_{j}\right)^{2} \times \sum_{j=1}^{n}\left(e_{j}\right)^{-2}
$$

- Step 5: Construct the weighted normalized matrix. 
Because of difference of each evaluation index, it needs to construct the weighted normalized matrix $\left(S_{i j}\right)_{m \times n}$.

$$
S=\left(S_{i j}\right)_{m \times n}=\left(\begin{array}{cccc}
w_{1} p_{11} & w_{2} p_{12} & \cdots & w_{n} p_{1 n} \\
w_{1} p_{21} & w_{2} p_{22} & \cdots & w_{n} p_{2 n} \\
\vdots & \vdots & & \vdots \\
w_{1} p_{m 1} & w_{2} p_{m 2} & \cdots & w_{n} p_{m n}
\end{array}\right)
$$

- Step 6: Determine the positive ideal and negative ideal solutions.

Positive ideal solution:

$$
V^{+}=\left\{\left(\max _{i} S_{i j} \mid j \in J_{1}\right),\left(\min _{i} S_{i j} \mid j \in J_{2}\right) \mid i=1,2, \cdots, m\right\}
$$

Negative ideal solution:

$$
V^{-}=\left\{\left(\min _{i} S_{i j} \mid j \in J_{1}\right),\left(\max _{i} S_{i j} \mid j \in J_{2}\right) \mid i=1,2, \cdots, m\right\}
$$

In both solutions explained above, $J_{1}$ and $J_{2}$ respectively represent the set of positive and negative attributes.

- Step 7: Calculate the distance measures (separation from PIS and NIS) for each alternative.

The distance from the positive ideal alternative is:

$$
D_{i}^{+}=\sqrt{\sum_{j=1}^{n}\left(S_{i j}-V_{j}^{+}\right)^{2}}
$$

Similarly, the distance from the negative ideal alternative is:

$$
D_{i}^{-}=\sqrt{\sum_{j=1}^{n}\left(S_{i j}-V_{j}^{-}\right)^{2}}
$$

- Step 8: Calculate the relative closeness to ideal solution $C_{i}$.

$$
C_{i}=\frac{D_{i}^{-}}{D_{i}^{+}+D_{i}^{-}}
$$

Here, $i=1,2, \cdots, m$

In this step, the option with $C_{i}$ closer to 1 is chosen.

- Step 9: Rank the preference order.

In this step, the decision-maker selects the high ranked alternative.

\section{Empirical Analysis}

After searching the related criteria on port competitiveness factors, the main criteria are divided into three categories of port throughput, port facilities criteria in Busan port and Shanghai port, as followings:

- Port throughput criteria: throughput (TEU, 2014), and increase/decrease rate of throughput (\%, 2000 to 2014).

- Port facilities criteria (2012): berth length (m), the number of C/C, the number of berth, total area (m2), depth $(\mathrm{m})$, and storage area $\left(\mathrm{m}^{2}\right)$.

\subsection{Analysis on Port Competitiveness by Port Throughput Criteria}

1) Construct the Normalized Matrix

Based on collected data, we made the normalized matrix of port throughput criteria in Busan port and Shanghai port by Equations (1) and (2).

$$
P_{1}=\left(\begin{array}{llll}
0.346 & 0.530 & 0.650 & 0.780 \\
0.654 & 0.470 & 0.350 & 0.220
\end{array}\right)
$$

2) Calculate the Entropy 
In this step, we made the construct the weighted normalized matrix of port throughput criteria in Busan port and Shanghai port by Equations (3), (4) and (5).

$$
S_{1}=\left(\begin{array}{llll}
0.159 & 0.146 & 0.122 & 0.084 \\
0.121 & 0.154 & 0.160 & 0.145
\end{array}\right)
$$

3) Determine the Ideal Solutions and the Distance Measures

After calculating the entropy, we determined the positive ideal and negative ideal solutions of port throughput criteria in Busan port and Shanghai port by Equations (6) and (7). And then, we calculated the distance measures of port throughput criteria in Busan port and Shanghai port by Equations (8) and (9).

Table 2 shows solutions and the distance of throughput criteria.

4) Ranking Port Competitiveness Attributes of Port Throughput using TOPSIS (10).

As shown in Table 3, there is a large gap between Shanghai port (0.575) and Busan port (0.409) of the port competitiveness in port throughput attributes. Their increasing rates of the container throughput were increased 5.6\% (Busan port) and 5.0\% (Shanghai port), but port throughput of Shanghai port was more than port throughput of Busan port twice as close. On the other hand, transshipment cargo volume of Busan port was more than transshipment cargo volume of Shanghai port twice as close. This result means that port throughput and its increasing rates of the world No. 1 container port Shanghai port is more competitive than high transshipment cargo volume and its increasing rates of Busan port.

\subsection{Analysis on Port Competitiveness by Port Facilities Criteria}

1) Construct the Normalized Matrix

Based on collected data, we made the normalized matrix of port facilities criteria in Busan port and Shanghai port by Equations (1) and (2).

$$
P_{2}=\left(\begin{array}{llllll}
0.505 & 0.445 & 0.560 & 0.525 & 0.513 & 0.856 \\
0.495 & 0.555 & 0.494 & 0.475 & 0.487 & 0.144
\end{array}\right)
$$

2) Calculate the Entropy

In this step, we made the construct the weighted normalized matrix of port facilities criteria in Busan port and Shanghai port by Equations (3), (4) and (5).

$$
S_{2}=\left(\begin{array}{llllll}
0.150 & 0.156 & 0.150 & 0.147 & 0.149 & 0.058 \\
0.151 & 0.142 & 0.151 & 0.154 & 0.152 & 0.121
\end{array}\right)
$$

3) Determine the Ideal Solutions

After calculating the entropy, we determined the positive ideal and negative ideal solutions of port facilities criteria in Busan port and Shanghai port by Equations (6) and (7). And then, we calculated the distance measures of port facilities criteria in Busan port and Shanghai port by Equations (8) and (9).

Table 2. Ideal solutions and the distance of throughput criteria.

\begin{tabular}{ccccccc}
\hline & Throughput & Throughput Rate & T/S & T/S Rate & Busan & Shanghai \\
\hline Positive & 0.159 & 0.154 & 0.160 & 0.145 & 0.020 \\
Negative & 0.121 & 0.146 & 0.122 & 0.084 & 0.014 \\
\hline
\end{tabular}

Table 3. The ranking port competitiveness attributes of port throughput.

\begin{tabular}{ccc}
\hline Rank & Ports & Port Throughput Competitiveness \\
\hline 1 & Shanghai & 0.575 \\
2 & Busan & 0.409 \\
\hline
\end{tabular}


Table 4 shows solutions and the distance of port facilities criteria.

4) Ranking Port Competitiveness Attributes of Port Facilities using TOPSIS (10).

Finally, we ranked the port competitiveness of port facilities in Busan port and Shanghai port by Equation

As shown in Table 5, the port competitiveness of port facilities in Busan port appeared to be somewhat higher than the port competitiveness of port facilities in Shanghai port. This is that Korean government has been the investment as North-East Asia main hub port policy around Busan port. As a result, competitiveness of Busan port more competitive than competitive port in Shanghai port in terms of the port facilities.

\subsection{Results of Analysis}

Looking at the comprehensive competitiveness of Busan port and Shanghai port, the comprehensive competitiveness of Shanghai port (0.588) is more competitive than the comprehensive competitiveness of Busan port (0.448).

Shanghai port has the lack of competitiveness of port facilities than Busan port, but it has more completive than Busan port in port throughput part. This results can imply to Busan port because that the transshipment rates of Busan port is growing and port throughput increasing rates is slowdown now.

Lastly determined total competitiveness and ranking of each competitiveness are as shown in Table 6.

\section{Conclusions}

North East Asia has favorable conditions as the growth pole of the world economy because it can link to North America through the Pacific Ocean and also link to Europe through the continent based on its geographic proximity.

The growth and the geopolitical advantages of North East Asia are directly related to shipping market. Therefore, the importance of the role of port facilities and port competitiveness is emerging. For the role of bridge of logistics in North East Asia that concentrating port throughput of the world, port competitiveness is essential. In this environment, North East Asia main hub port strategies around Busan port are experiencing difficulties because of the rapidly growth of the Chinese ports. In response to these environments, and in order to sustained growth for improving the competitiveness, we examined port competitiveness of Busan port in Korea and Shanghai port in China.

As a result, it indicates that Shanghai port is more competitive than Busan port in total competitiveness and port throughput criteria, and Busan port is more competitive than Shanghai port in port facilities criteria.

Another alternative, it needs to efforts that trying to find the port by shipping companies as the port service

Table 4. Ideal solutions and the distance of port facilities criteria.

\begin{tabular}{ccccccccc}
\hline & Length & The Number of C/C & The Number of Berth & Total Area & Depth & Storage Area & Busan & Shanghai \\
\hline Positive & 0.151 & 0.156 & 0.151 & 0.154 & 0.152 & 0.121 & 0.0119 & 0.0040 \\
Negative & 0.150 & 0.142 & 0.150 & 0.147 & 0.149 & 0.058 & 0.0118 & 0.0038 \\
\hline
\end{tabular}

Table 5. The ranking port competitiveness attributes of port facilities.

\begin{tabular}{ccc}
\hline Rank & Ports & Port Throughput Competitiveness \\
\hline 1 & Busan & 0.497 \\
2 & Shanghai & 0.490 \\
\hline
\end{tabular}

Table 6. The results of analysis.

\begin{tabular}{ccccc}
\hline Rank & Ports & Total Competitiveness & Port Throughput & Port Facilities Competitiveness \\
\hline 1 & Shanghai & 0.588 & 0.575 & 0.490 \\
2 & Busan & 0.448 & 0.409 & 0.497 \\
\hline
\end{tabular}


factors, namely agility $\cdot$ safety $\cdot$ punctuality improves the quality of port logistics services. Also, not only for continuous operations of shipping companies, but also for launch a new operation of the shipping companies, it is needs to adopt various incentive programs for attracting transshipment cargo volume. Finally, it also needs to focus on securing port throughput through strategic alliance with the adjacent ports and port throughput centralization strategies.

In this changing of port environment, Korean government is pushing to the hub port in Northeast Asia strategy with a focus on Busan port, however, there are a lot of difficulties in promoting it In this context, we seek the strategy alternatives for continuous port competitiveness improvement in rapidly changing of environment in Northeast Asia shipping. We compare port competitiveness between Busan port and Shanghai port using TOPSIS, and we seek ways to port competitiveness improvement in Korea especially Busan port.

However, as further study, it may be a good idea to add the transshipment cargo volume in port throughput part, related port hinterland factors in port physical part and tariff or port dues in financial part to the results of this research.

\section{References}

[1] Saeed, N. (2009) An Analysis of Carriers' Selection Criteria When Choosing Container Terminals in Pakistan. Maritime Economic and Logistics, 11, 270-288. http://dx.doi.org/10.1057/mel.2009.8

[2] Sayareh, J. and Alizmini, H.R. (2014) A Hybrid Decision-Making Model for Selecting Container Seaport in the Persian Gulf. Asian Journal of Shipping \& Logistics, 30, 75-95. http://dx.doi.org/10.1016/j.ajsl.2014.04.004

[3] Mangan, J., Lalwani, C. and Gardner, B. (2002) Modelling Port/Ferry Choice in RoRo Freight Transportation. International Journal of Transport Management, 1, 15-28. http://dx.doi.org/10.1016/S1471-4051(01)00003-9

[4] Nir, A., Lin, K. and Liang, G. (2003) Port Choice Behavior-From the Perspective of the Shipper. Maritime Policy and Management, 30, 165-173. http://dx.doi.org/10.1080/0308883032000069262

[5] Tiwari, P., Itoh, H. and Doi, M. (2003) Shippers' Containerized Cargo Transportation Behaviour in China: A Discrete Choice Analysis. Journal of Transportation Economics and Statistics, 6, 71-87.

http://www.palgrave-journals.com/mel/journal/v5/n1/pdf/9100062a.pdf

[6] Malchow, M. and Kanafani, A. (2001) A Disaggregate Analysis of Factors Influencing Port Selection. Maritime Policy and Management, 28, 265-277. http://dx.doi.org/10.1080/03088830110060840

[7] Malchow, M.B. and Kanafani, A. (2004) A Disaggregate Analysis of Port Selection. Transportation Research Part E, 40, 317-337. http://dx.doi.org/10.1016/j.tre.2003.05.001

[8] Yeo, K.T., Lee, H.G. and Oh, S.W. (2004) Extraction of Port Selection Factors for Increasing Shippers'Attraction of Small and Medium Ports (Written in Korean). Journal of Shipping and Logistics, 43, 33-53. http://www.papersearch.net/view/detail.asp?detail_key=13500831\&code=CP00000002

[9] Yeo, G.T., Roe, M. and Dinwoodie, J. (2008) Evaluating the Competitiveness of Container Ports in Korea and China. Transportation Research Part A, 42, 910-921. http://dx.doi.org/10.1016/j.tra.2008.01.014

[10] Tongzon, J.L. (1995) Determinants of Port Performance and Efficiency. Transportation Research Part A, 29, $245-252$. http://dx.doi.org/10.1016/0965-8564(94)00032-6

[11] Tongzon, J.L. and Sawant, L. (2007) Port Choice in a Competitive Environment: from the Shipping Lines’ Perspective. Applied Economics, 39, 477-492. http://dx.doi.org/10.1080/00036840500438871

[12] Tongzon, J.L. (2009) Port Choice and Freight Forwarders. Transportation Research Part E, 45, 186-195. http://dx.doi.org/10.1016/j.tre.2008.02.004

[13] Ugboma, C., Ugboma, O. and Ogwude, I. (2006) An Analytic Hierarchy Process (AHP) Approach to Port Selection Decisions-Empirical Evidence from Nigerian Ports. Maritime Economics and Logistics, 8, 251-266. http://dx.doi.org/10.1057/palgrave.mel.9100160

[14] Grosso, M. and Monteiro, F. (2008) Relevant Strategic Criteria When Choosing a Container Port: The Case of the Port of Genoa. Association for European Transport and Contributors, 1-21. http://worldcat.org/issn/14749122

[15] Song, D.W. and Yeo, K.T. (2004) A Completive Analysis of Chinese Container Ports Using the Analytic Hierarchy Process. Maritime Economics and Logistics, 6, 34-52. http://dx.doi.org/10.1057/palgrave.mel.9100096

[16] Lirn, T.C., Thanopoulou, H.A., Beynon, M.J. and Beresford, A.K.C. (2004) An Application of AHP on Transshipment Port Selection: A Global Perspective. Maritime Economics \& Logistics, 6, 70-91. http://dx.doi.org/10.1057/palgrave.mel.9100093

[17] Cullinane, K. and Wang, T.F. (2006) Chapter 23 Data Envelopment Analysis (DEA) and Improving Container Port Efficiency. Research in Transportation Economics, 17, 517-566. 
[18] Chang, Y.T., Lee, S.Y. and Tongzon, J.L. (2008) Port Selection Factors by Shipping Lines: Different Perspectives between Trunk Liners and Feeder Service Providers. Marine Policy, 32, 877-885.

http://dx.doi.org/10.1016/j.marpol.2008.01.003 